\title{
Status of Cassava Begomoviruses and Their New Natural Hosts in Nigeria
}

\author{
F. O. Ogbe, International Institute of Tropical Agriculture (IITA), Ibadan, Nigeria and National Root Crops Research \\ Institute (NRCRI), Umudike, Umuahia, Nigeria; and A. G. O. Dixon, J. d'A. Hughes, O. J. Alabi, and \\ R. Okechukwu, IITA, Ibadan, Nigeria
}

\begin{abstract}
Ogbe, F. O., Dixon, A. G. O., Hughes, J. d’A., Alabi, O. J., and Okechukwu, R. 2006. Status of cassava begomoviruses and their new natural hosts in Nigeria. Plant Dis. 90:548-553.

A diagnostic survey was conducted in 2002-03 to determine the status of cassava mosaic begomoviruses in Nigeria and to ascertain if the virulent Ugandan variant of East African cassava mosaic virus (EACMV-Ug2) was present. Of the 418 farms visited, $48 \%$ had cassava with moderately severe or severe symptoms, whereas $52 \%$ had cassava with mild symptoms. These distributions were at random. Of the 1,397 cassava leaf samples examined, 1,106 had symptoms. In polymerase chain reaction tests, $74.1 \%$ of the symptom-bearing samples tested positive for African cassava mosaic virus (ACMV) alone, $0.3 \%$ for EACMV alone, $24.4 \%$ for mixed infections by the two viruses, and $1.2 \%$ did not react with any of the primers used. The two viruses also were detected in $32 \%$ of the 291 symptomless plants and in the whitefly vector samples. EACMV-Ug2, Indian cassava mosaic virus, and South African cassava mosaic virus were not detected in any of the whitefly or leaf samples. Most farms had ACMV in single infection as well as in mixed infections with EACMV. Most doubly infected plants showed severe symptoms. Two biological variants of ACMV were identified based on symptom expression on cassava in the field. ACMV and EACMV were detected in the leguminous plant Senna occidentalis (L.) Link and the weed Combretum confertum Lams.; these are new natural hosts of the viruses. Although the virulent EACMV-Ug2 was not detected, the occurrence of variants of ACMV and a high proportion of mixed infections by ACMV and EACMV, which could result in recombination events such as the one that produced EACMV-Ug2, demands appropriate measures to safeguard cassava production in Nigeria.
\end{abstract}

Cassava begomoviruses in sub-Saharan Africa include African cassava mosaic virus (ACMV), East African cassava mosaic virus (EACMV), and South African cassava mosaic virus (SACMV) $(2,3,9)$. Cassava (Manihot esculenta Cranz) is the most common natural host of the viruses, followed by its relative wild species $M$. glaziovii Muller von Argau. Shoyinka et al. (19) reported that the castor oil plant (Ricinus communis L.) is a natural host of ACMV and EACMV in Nigeria. Other than that report, there is limited information on the natural hosts of cassava begomoviruses in sub-Saharan Africa.

The viruses cause cassava mosaic disease (CMD), the most important viral disease of cassava in sub-Saharan Africa $(6,16)$. Yield losses are enormous, especially if susceptible cultivars are cultivated.

Corresponding author: F. O. Ogbe

E-mail: F.Ogbe@ cgiar.org

francisogbe@yahoo.com

Accepted for publication 21 December 2005.

DOI: 10.1094/PD-90-0548

(C) 2006 The American Phytopathological Society
On such cultivars, 90 to $100 \%$ yield losses were recorded in Uganda during a recent CMD pandemic (15). The pandemic was caused by a Ugandan strain of EACMV (EACMV-Ug2), which is a novel recombinant between ACMV and EACMV (22). Symptoms are very severe when EACMV$\mathrm{Ug} 2$ and ACMV co-infect cassava plants. Many farmers in Uganda abandoned cassava cultivation at the peak of the pandemic (15).

CMD has been spreading from Uganda to neighboring countries and beyond. It has reached the Democratic Republic of (DR) Congo (10), indicating its spread toward West African countries. This poses a serious threat to cassava production in Nigeria, because only one country separates Nigeria from DR Congo. To sustain Nigeria's position as the world-leading producer of cassava, a project on preemptive management of a severe form of CMD caused by EACMV-Ug2 was initiated. One of the objectives of the project was to conduct a comprehensive survey to determine the status of CMD and of cassava mosaic begomoviruses in Nigeria so as to ascertain whether EACMV-Ug2 was already in the country. The outcome of the survey is presented in this article.

\section{MATERIALS AND METHODS}

Survey routes and sample collection. The survey was conducted between December 2002 and December 2003. The survey routes were determined using the road maps of Nigeria, which included highways, secondary roads, and feeder roads. As much as possible, the routes were chosen to intersect the main cassava-growing areas and to ensure that sufficient cassava fields were available for sampling. Along the routes, cassava fields were visited at intervals of 10 to 15 $\mathrm{km}$ in southern Nigeria, where cassava fields were common. In the north, however, the sampling interval was about 20 to $30 \mathrm{~km}$ because cassava fields were sparsely spaced. In all, 418 fields were visited. In each field, the coordinates were recorded using a global positioning system (GPS; Magellan GPS 315, San Dimas, CA). CMD symptom severity was rated on a scale of 1 to 5 , where $1=$ no symptoms and $5=$ severe mosaic with distortion of the entire leaf (21). An overall impression of symptom severity of CMD for each field was recorded as mild (if CMD severity score was 2), moderately severe (if the score was 3 ), or severe (if the score was either 4 or 5). A leaf sample was collected from a representative plant that was symptomless or showing mild, moderately severe, or severe symptoms. On average, three samples were collected per field, depending on the number of plants showing different levels of CMD severity. Of the 1,397 leaf samples collected, 1,106 were symptomatic and 291 were symptomless. A description of the symptoms observed on the sampled plant was made. Particular attention was paid to different symptoms on different plants of the same genotype.

Leaf samples of weeds showing characteristic symptoms of mosaic in or near the cassava fields also were collected. If present, whiteflies were collected with the use of an aspirator in each field; in all, 283 samples were collected and preserved in $70 \%$ ethanol in Eppendorf tubes. During the survey trip, whitefly and leaf samples were kept at $4^{\circ} \mathrm{C}$ in a mobile refrigerator (model V 200; Norcold Sidney, a subsidiary of Thetford Corporation, Ann Arbor, $\mathrm{MI})$. The samples were stored at $-20^{\circ} \mathrm{C}$ in the laboratory during analysis. 
DNA extraction. Total DNA was extracted from the cassava and weed samples according to the procedure of Dellaporta et al. (4). The same procedure was used to extract the total DNA from three to six whiteflies from each whitefly sample. However, for whiteflies, the volumes of the reagents were reduced fivefold to avoid over dilution of the DNA. For the leaf samples, the extracted DNA was resuspended in $200 \mu \mathrm{l}$ of Tris-EDTA (TE; Tris$\mathrm{HCl}, 50 \mathrm{mM}$ and EDTA, $10 \mathrm{mM}$ ), $\mathrm{pH} 8.0$, whereas the DNA samples from the whiteflies were resuspended in $50 \mu \mathrm{l}$ of TE, $\mathrm{pH}$ 8.0 , and stored at $-20^{\circ} \mathrm{C}$.

Testing of the DNA samples by polymerase chain reaction. DNA from leaf

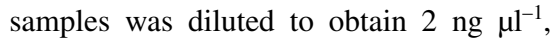
whereas the DNA from the whitefly samples was used undiluted. The primers used were ACMV-AL1/F/AR0/R for the detection of open reading frames (ORFs) AC1 and AV2 of ACMV (22); JSP001/002 for ORF AV1 of ACMV; JSP001/003 for ORF AV1 of EACMV (18); UV-AL3/F/UVAL1/R2 for ORFs AC3 and AC1 of most strains of EACMV; UV-AL1/F/ACMV$\mathrm{CP} / \mathrm{R} 3$ for ORFs $\mathrm{AC} 1$ and AV1 specific for Ugandan EACMV strain EACMV-Ug2 (22); Indian cassava mosaic virus (ICMV)-F1/R2 for the intergenic region and ORF AV2 of ICMV (9); SACMV$\mathrm{CP}^{\prime} / \mathrm{CP} 3^{\prime}$ for ORF AV1 of SACMV (1); and PRIMER A/B degenerate primers for the common region of whitefly-transmitted geminiviruses (5). The reaction mixture per tube contained $2.5 \mu \mathrm{l}$ of thermobuffer (10x concentration), $1.5 \mu \mathrm{l}$ of $\mathrm{MgCl}_{2}$ (25 $\mathrm{mM}), 2.0 \mu \mathrm{l}$ of dNTPs $(2.5 \mathrm{mM}), 1.3 \mu \mathrm{l}$ each of forward and reverse primers (10 $\mathrm{pM}$ for specific primers, $10 \mathrm{pM}$ or $100 \mathrm{pM}$ for degenerate primers), $0.2 \mu \mathrm{l}$ (1 unit) of Taq DNA polymerase (Promega product; Promega Corporation, Madison, W1), 12.9 $\mu \mathrm{l}$ of sterilized distilled water, and $3.3 \mu \mathrm{l}$ of DNA sample (25.0 $\mu \mathrm{l}$ per reaction tube). The DNA extraction buffer and DNA of virus-free healthy cassava were used as negative controls. The healthy negative control cassava clone TMS 30572 was obtained from virus-tested in vitro plantlets from Tissue Culture Unit, International Institute of Tropical Agriculture (IITA), Ibadan, Nigeria. Legg [cl] of IITA Uganda provided DNA of EACMV-Ug2 through the Nigerian Plant Quarantine Service, Moore Plantation, Ibadan. This was used as the positive control for the detection of the virus. The reaction cycles using a PTC DNA Engine system (model PTC 200; MJ Research, Inc., Watertown, MA) were as reported by Zhou et al. (22).
The polymerase chain reaction (PCR) products were separated by electrophoresis in a $1 \%$ agarose gel. The DNA bands were observed under UV light and positive and negative reactions were recorded. Photographs of some of the gels were taken using a Polaroid camera (Polaroid Gelcam; Polaroid Corporation, Cambridge, MA).

\section{RESULTS}

CMD status in farmers' fields. CMD symptoms were mild in most farms in Akwa Ibom, Anambra, and Enugu states (southeastern part of Nigeria; Fig. 1); Delta, Edo, and Lagos states (southwest); Kwara, Nasarawa, and Niger states (middle belt); Jigawa state (northeast), and Kaduna state (northwest). CMD symptoms were either moderately severe or severe in most farms in Cross River, Abia, Ebonyi, and Imo states (southeast; Fig. 1); Ekiti and Ondo states (southwest); Benue and Kogi states (middle belt); Bauchi and Gombe states (northeast); and Kebbi state (northwest). The number of farms with either moderately severe or severe symptoms was about the same as the number with mild symptoms in Rivers state (southeast; Fig. 1); Ogun, Osun, and Oyo states (southwest); and Taraba state (northeast).

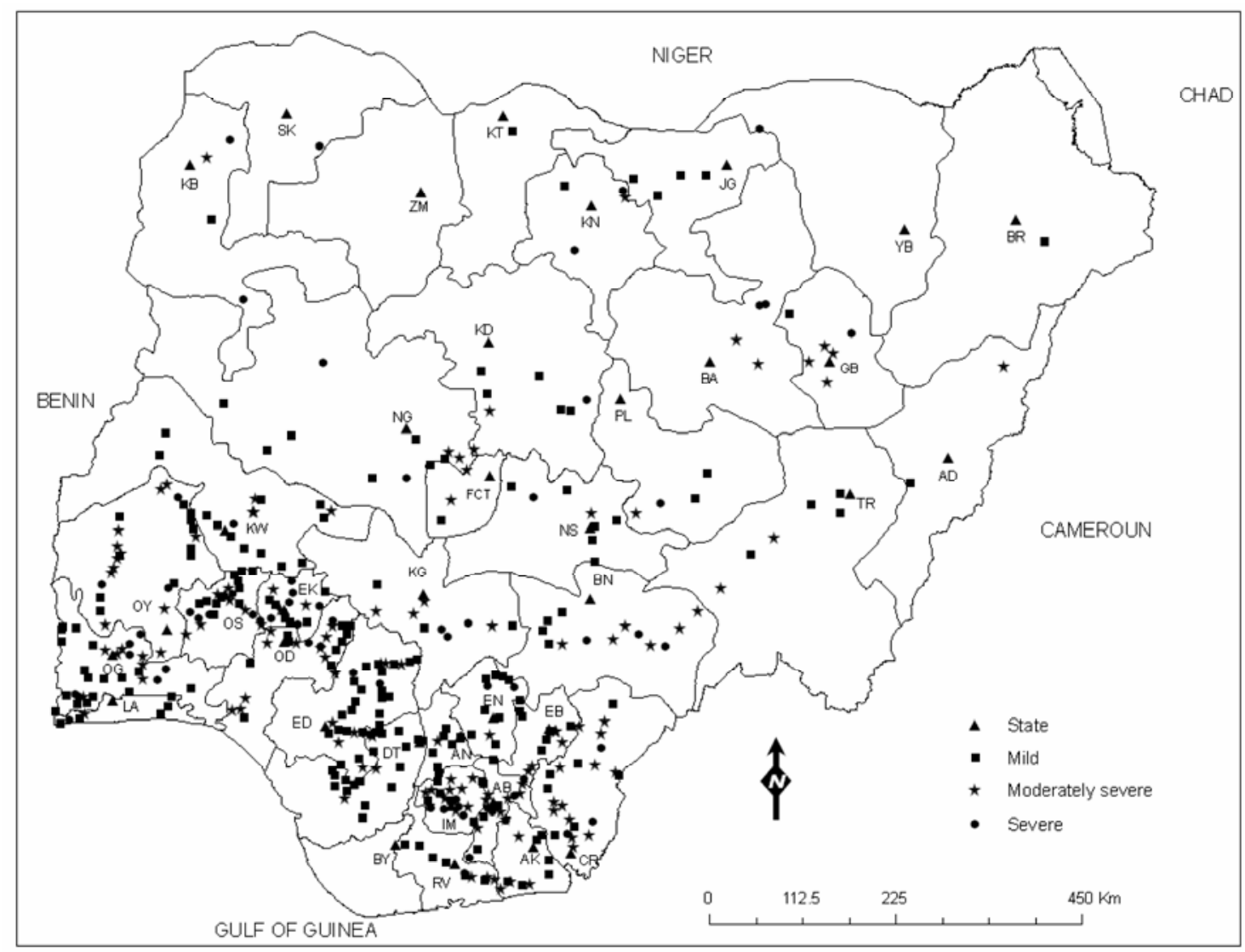

Fig. 1. Distribution of cassava farms in Nigeria showing different cassava mosaic disease (CMD) severity during a diagnostic survey in 2002-03. The country is partitioned into states as follows: southeast: $\mathrm{CR}=$ Cross River, $\mathrm{AK}=\mathrm{Akwa}$ Ibom, $\mathrm{RV}=$ Rivers, $\mathrm{BY}=\mathrm{Bayelsa}, \mathrm{IM}=\mathrm{Imo}, \mathrm{AB}=\mathrm{Abia}, \mathrm{AN}=\mathrm{Anambra}$, $\mathrm{EB}=$ Ebonyi, and $\mathrm{EN}=$ Enugu; southwest: $\mathrm{OG}=$ Ogun, $\mathrm{LA}=\mathrm{Lagos}, \mathrm{OY}=\mathrm{Oyo}, \mathrm{OS}=$ Osun, $\mathrm{EK}=$ Ekiti, ON = Ondo, ED = Edo, and DT = Delta; middle belt: $\mathrm{BN}=$ Benue, $\mathrm{KG}=\mathrm{Kogi}, \mathrm{KW}=\mathrm{Kwara}, \mathrm{NS}=$ Nasarawa, $\mathrm{FCT}=$ Federal Capital Territory, $\mathrm{NG}=$ Niger, and $\mathrm{PL}=\mathrm{Plateau}$; northeast: TR $=$ Taraba, $\mathrm{AD}=$ Adamawa, $\mathrm{GB}=$ Gombe, $\mathrm{BA}=$ Bauchi, $\mathrm{BR}=$ Borno, $\mathrm{YB}=$ Yobe, and JG = Jigawa; and northwest: $\mathrm{KB}=$ Kebbi, $\mathrm{SK}=\mathrm{Sokoto}, \mathrm{ZM}=\mathrm{Zamfara}, \mathrm{KT}=\mathrm{Katsina}$, $\mathrm{KN}=\mathrm{Kano}$, and $\mathrm{KD}=$ Kaduna . 
Overall, symptoms were either moderately severe or severe in $48 \%$ of the farms. The farms with cassava with moderate or severe symptoms and mild symptoms were fairly randomly distributed.

Cassava mosaic begomoviruses. Among the 1,106 leaf samples from the symptom-bearing cassava plants, $74.1 \%$ tested positive for ACMV alone, $0.3 \%$ for EACMV alone, $24.4 \%$ for mixed infections with the two viruses, and $1.2 \%$ failed to give a PCR product with any of the primers. Of the 291 samples from symptomless plants, $27.2 \%$ were infected with ACMV alone, none tested positive to EACMV alone, $4.8 \%$ tested for both viruses, and $68.0 \%$ apparently were not infected with any of the cassava begomoviruses.

Farms in which only ACMV was detected and farms in which the virus occurred in single infection as well as in mixed infections with EACMV predominated (Fig. 2). Few farms contained EACMV in single infection in addition to mixed infections by ACMV and EACMV; these were located in Enugu and Niger states. ACMV and EACMV were detected singly in only one farm in Ebonyi state. Unidentified begomoviruses were detected in Ogun, Lagos, Ekiti, Ondo, Nasarawa, Plateau, and Gombe states (Fig. 2).

EACMV-Ug2 was not detected in any of the leaf samples (Fig. 3). The six cassava leaf samples in lanes 1 to 6 and 11 to 16 (Fig. 3A) tested positive to both viruses. The EACMV primers also detected the DNA of the EACMV-Ug2 that was used as the positive control (Fig. 3A, lanes 17 and 18). However, EACMV-Ug2 was differentiated from the Nigerian isolates of EACMV by the EACMV-Ug2-specific primers (Fig. 3B, lanes 7 and 8). Lanes 9 and 10 (Fig. 3A and B) and 19 and 20 (Fig. 3B) contained samples for the negative control and, hence, no band was observed. SACMV and ICMV were not detected in the leaf samples. ACMV and EACMV in single and double infections also were detected in the whitefly vector across the country (data not shown).

Biological variants of ACMV on cassava. When plants of the same genotypes in the same farm were observed for symptoms, three types of mosaic patterns were noticed. These were yellow-green mosaic, whitish/bleaching-green mosaic (Fig. 4), and a combination of the two types. The yellow-green mosaic usually was accompanied with mild leaf distortion (Fig. 4A).
The whitish/bleaching-green mosaic was, in most cases, associated with severe leaf distortion (Fig. 4B). A healthy leaf is green, without blemish and undistorted (Fig. 4C). ACMV and EACMV separately induced the yellow-green mosaic, whereas ACMV was mainly responsible for the whitish/bleaching-green mosaic (Table 1). The two viruses in mixed infections also were detected in plants separately showing the two types of symptoms and with a combination of the two types (Table 1). Although ACMV alone induced severe symptoms on some plants, most plants coinfected by ACMV and EACMV usually expressed severe symptoms.

New natural host of ACMV and EACMV. ACMV and EACMV co-infected a leguminous weed, Senna occidentalis (L.) Link, showing mosaic symptoms (Fig. 5A (i)) as diagnosed by PCR (Fig. 6, lanes 1 and 15). The two viruses also co-infected Combretum confertum Lams., showing very bright mosaic symptoms (Fig. 5B (i) I), which tested positive in PCR (Fig. 6 lanes 2, 9, and 16). ACMV was diagnosed in leaves of castor oil plant, (R. communis), exhibiting coalesced chlorotic spots (Fig. 5C (i)), using PCR (Fig. 6 lane 3 and 10 ). Healthy plants of $S$. occidentalis (Fig.

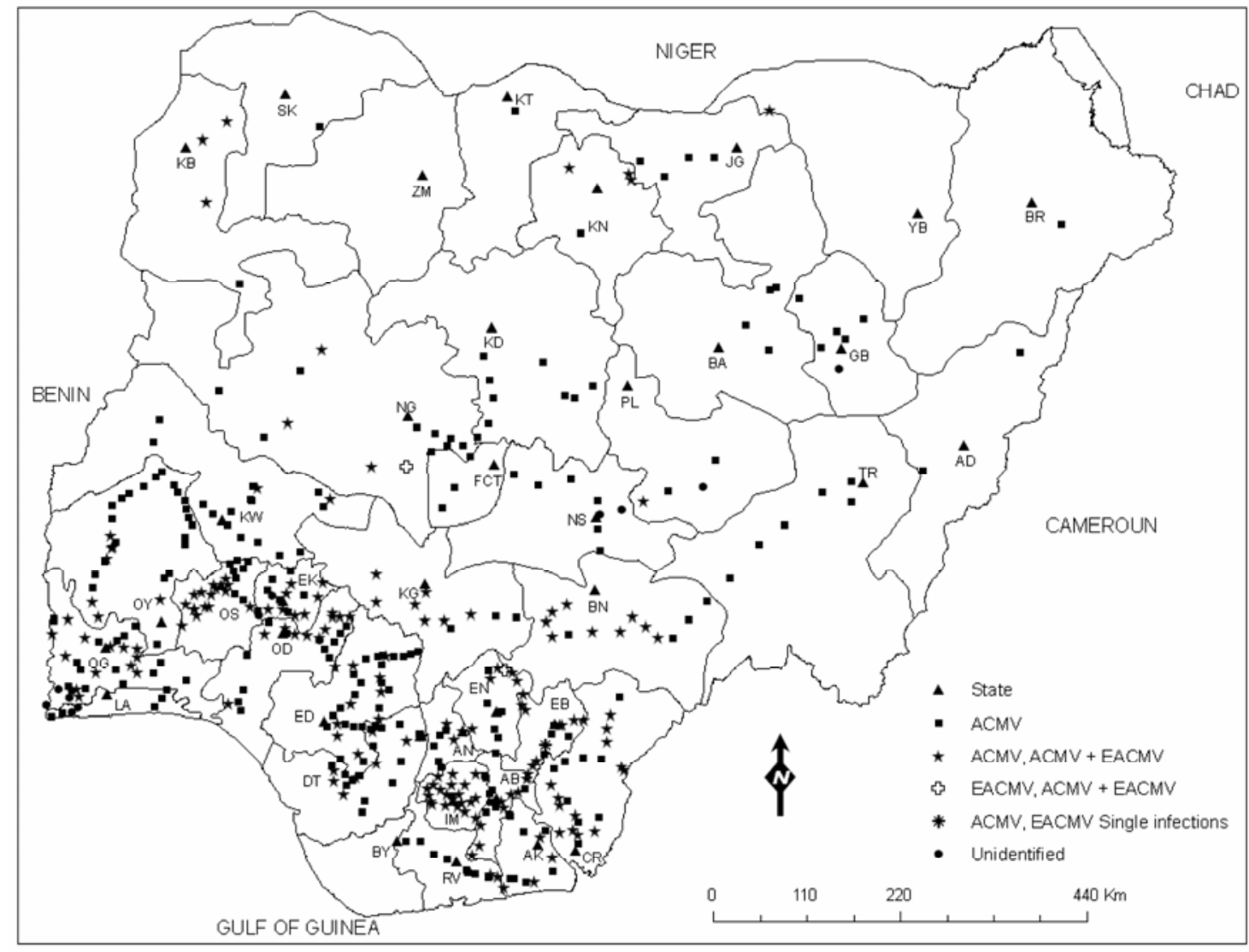

Fig. 2. Distribution of cassava farms in Nigeria in which cassava begomoviruses were detected either as single infection or single infection as well as mixed infections during a diagnostic survey in 200-03. The country is partitioned into states as follows: southeast: CR = Cross River, AK = Akwa Ibom, RV = Rivers, BY = Bayelsa, IM = Imo, AB = Abia, AN = Anambra, EB = Ebonyi, and EN = Enugu; southwest: OG = Ogun, LA = Lagos, OY = Oyo, OS = Osun, $\mathrm{EK}=$ Ekiti, $\mathrm{ON}=$ Ondo, $\mathrm{ED}=\mathrm{Edo}$, and DT = Delta; middle belt: BN = Benue, KG = Kogi, KW = Kwara, NS = Nassarawa, FCT = Federal Capital Territory, $\mathrm{NG}=$ Niger, and PL = Plateau; northeast: TR = Taraba, AD = Adamawa, GB = Gombe, BA = Bauchi, BR = Borno, YB = Yobe, JG = Jigawa; and northwest: $\mathrm{KB}=$ Kebbi, $\mathrm{SK}=$ Sokoto, $\mathrm{ZM}=$ Zamfara, $\mathrm{KT}=\mathrm{Katsina}, \mathrm{KN}=\mathrm{Kano}$, and $\mathrm{KD}=\mathrm{Kaduna}$. ACMV = African cassava mosaic virus, EACMV = East African cassava mosaic virus, and ACMV+EACMV = mixed infections of ACMV and EACMV. 
5A (ii)), C. confertum (Fig. 5B (ii), and a healthy leaf of $R$. communis (Fig. 5C (ii)) were as shown. Extracted DNA of wild cassava $M$. glaziovii which was collected during the survey tested positive for ACMV and EACMV (Fig. 6, lanes 4, 11, and 18). The DNA of an infected cassava leaf used as positive control tested positive (lanes 5, 12, and 19), whereas the DNA of a healthy cassava leaf did not react with any of the primers (lanes 6, 13, and 20). Positive bands also were not observed on lanes 7, 14, and 21 that contained buffer, also used as negative control.

\section{DISCUSSION}

The predominance of single infections of ACMV over single infections of EACMV in Nigeria had been reported from a survey conducted in 1997-98 (11). In that survey, EACMV was diagnosed in only 1 sample $(0.05 \%)$ in a single infection out of the 290 samples tested. This result was similar to the present survey in which 3 samples $(0.3 \%)$ yielded single infections of EACMV out of the 1,106 samples tested. Single infections of EACMV also were not common in Cote d'Ivoire (17) and Cameroon (7). This contrasts with the situation on the coastal areas of Tanzania and Kenya, and in Malawi and Madagascar, where single infections by EACMV predominate $(13,14,20)$. More and wider distribution of mixed infections by ACMV and EACMV was recorded in the present survey than in the survey conducted in 1997-98. The mixed infections were distributed across the entire country (Fig. 2) whereas, in the earlier survey, the distribution was from the south up to the middle belt (11). In addition, the 1997-98 survey found $9.3 \%$ mixed infections compared with the $24.1 \%$ in the present survey. More routes were covered, more farms were visited, and more plants per farm were sampled than in the 1997-98 to increase the sensitivity of the present survey, particularly with respect to detecting EACMV-Ug2. Intensive cultivation of cassava leading to possible indiscriminate movement of infected planting materials, and the dissemination of the ACMV and EACMV by whitefly vectors, also could be the cause of a greater number of farms with mixed infections.

It is important to note that the distribution of farms with cassava plants with either moderately severe or severe CMD symptoms (Fig. 1) was similar to the distribution of double infections by ACMV and EACMV (Fig. 2). This implies that the larger the number of farms where mixed infections were detected, the greater the number of farms with cassava with severe symptoms. Mixed infections by ACMV and EACMV with the associated severe symptoms have been reported in Uganda, Tanzania $(8,18)$, and Cameroon (7). It may be difficult to prevent mixed infections, whether by whitefly transmission or the planting of infected stem cuttings; therefore, the severe symptoms associated with such infections can be mitigated by cultivating resistant genotypes. This is what the CMD project aimed to achieve through the introduction of desirable resistant genotypes into the agroecologies of Nigeria.

Biological variants of ACMV reported by Ogbe et al. (12) were determined on Nicotiana benthamiana Domin., an experimental host. In the present study, two biological variants of ACMV based on symptoms on cassava were obvious (Table 1; Fig. 4). The two variants mostly coinfected cassava (Table 1), producing pos- sible synergistic effects that might be responsible for the severe symptoms observed in plants infected only with ACMV. Thus, mixed infections by ACMV and EACMV and mixed infections by variants of ACMV could be more common in Nigeria than single infections. This could partly account for the fairly high proportion $(48 \%)$ of farms with cassava showing either moderately severe or severe symptoms of CMD (Fig. 1). There is a need to provide farmers with new, improved cultivars with high levels of resistance to CMD.

Identification of ACMV and EACMV in S. occidentalis and C. confertum (Fig. 5A
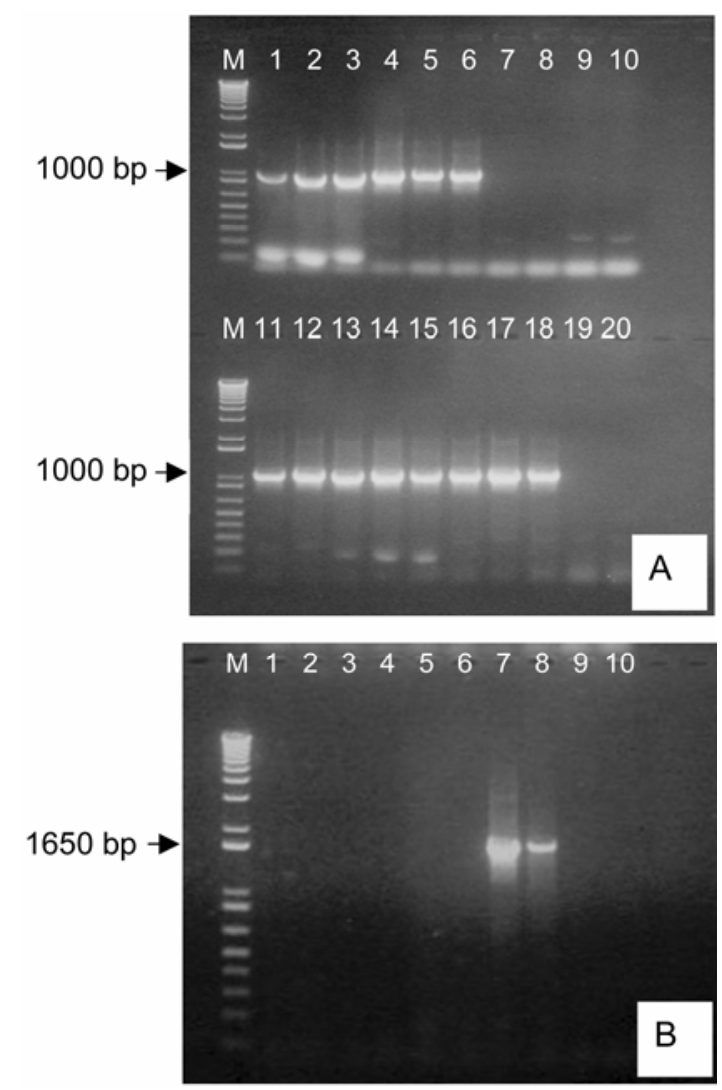

Fig. 3. Nigerian isolates of African cassava mosaic virus (ACMV) and East African cassava mosaic virus (EACMV) DNA fragments in mixed infections of cassava leaves amplified in polymerase chain reaction by three pairs of primers and analyzed by gel electrophoresis. A and B, Lanes 1-6 contained the total DNA of cassava leaf samples 75, 242, 503, 507, 647, and 796; lanes 7 and 8 contained the DNA of virulent Ugandan strain EACMV-Ug2 as positive control; and lanes 9 and 10 contained DNA of a healthy cassava leaf and buffer, respectively, as negative controls. A, The same samples also were arranged in a similar pattern for lanes 11-16, 17 and 18, and 19 and 20, respectively. The samples were tested by the following primers: A, lanes $1-10=$ ACMV-AL1/F/AR0/R for the detection of open reading frames (ORFs) AC1/AV2 of ACMV (22); A, lanes 11-20 = UV-AL3/F/AL1/R2 for ORFs AC3/AC1 of most strains of EACMV (22); B, lanes 1-10 = UV-AL1/F1/ACMV-CP/R3 for ORFs AC1/AV1 specific for Ugandan strain of EACMV (EACMV-Ug2) (22).

Table 1. Type of cassava mosaic disease symptoms on cassava associated with single and double infections by African cassava mosaic virus (ACMV) and East African cassava mosaic virus (EACMV) ${ }^{\mathrm{x}}$

\begin{tabular}{lcccc}
\hline & & \multicolumn{3}{c}{ Associated with (\%) } \\
\cline { 3 - 5 } Type of symptom & No. of plants assessed & ACMV & EACMV & Mixed $^{\mathbf{y}}$ \\
\hline Yellow-green mosaic & 174 & 78.7 & 1.7 & 19.6 \\
Whitish/bleaching-green mosaic $^{\text {Combination }}$ & 13 & 76.9 & 0.0 & 23.1 \\
& 207 & 68.1 & 0.0 & 31.9 \\
\hline
\end{tabular}

${ }^{x}$ Only plants of the same genotype were assessed in each field in this study.

${ }^{y}$ Mixed infections by ACMV and EACMV.

${ }^{\mathrm{z}}$ Combinations of the two symptom types. 

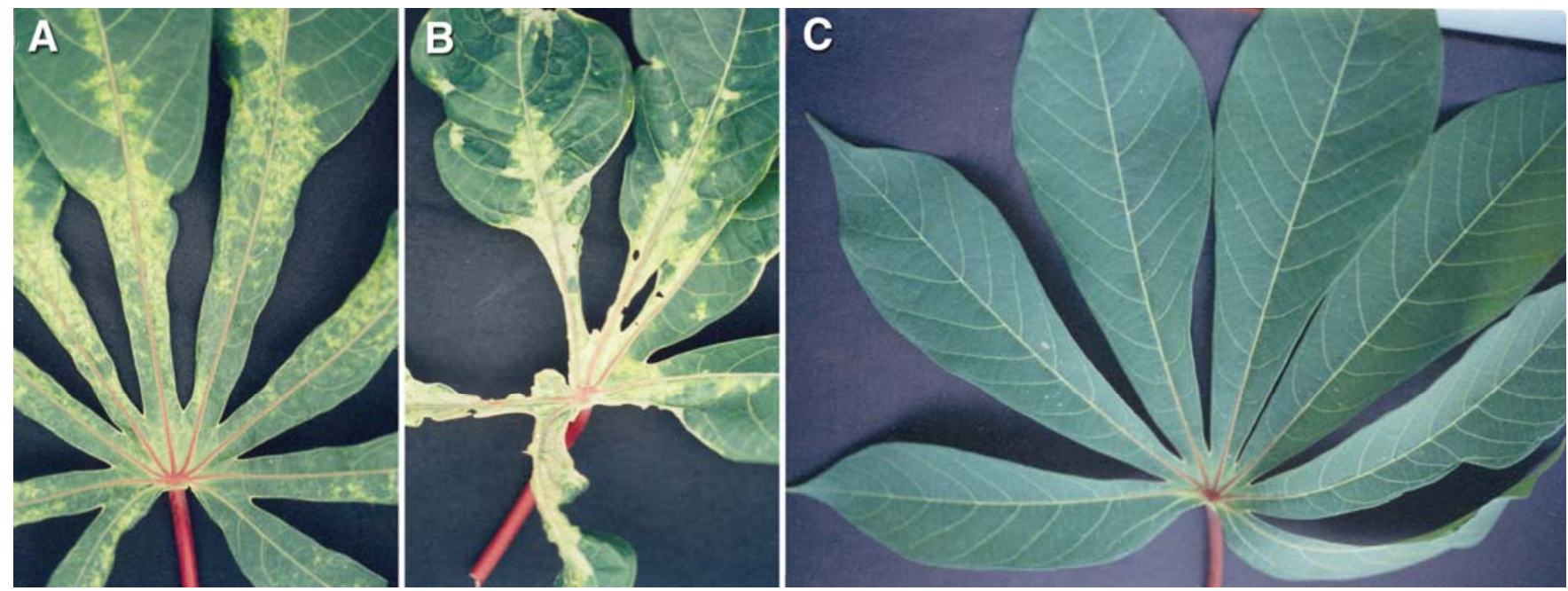

Fig. 4. Characteristic symptoms of two biological variants of African cassava mosaic virus (ACMV) on cassava leaves in Nigeria. The symptoms were observed on different plants of the same genotype in the same farm during a diagnostic survey in 2002-03 for cassava begomoviruses in Nigeria. A, Yellowgreen mosaic with mild leaf distortion, $\mathbf{B}$, whitish/bleaching-green mosaic with notable leaf distortion, and $\mathbf{C}$, symptomless leaf. Polymerase chain reaction showed that the two distinct symptoms were caused by ACMV.

A
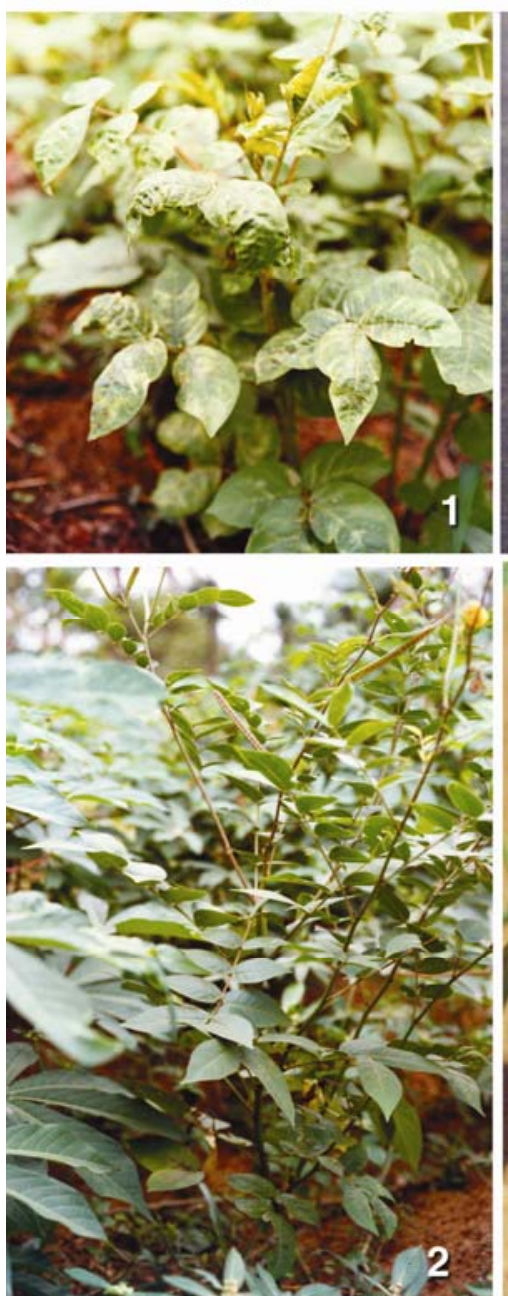

B
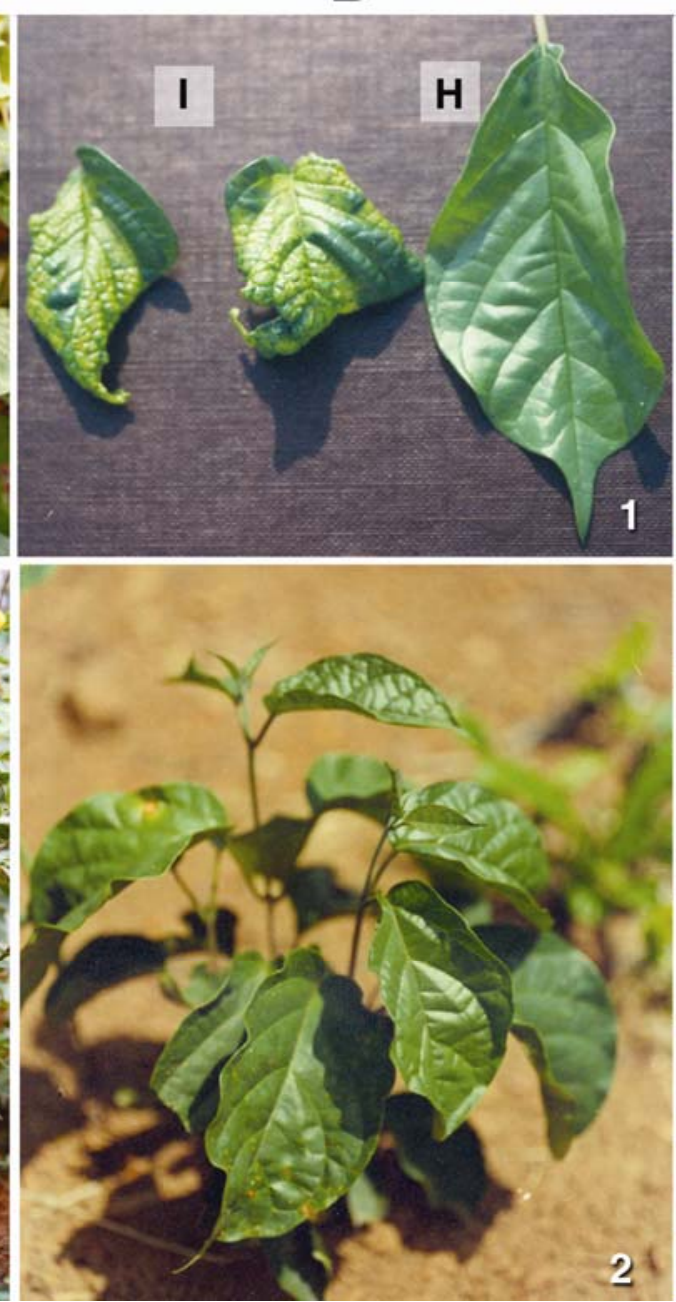

C
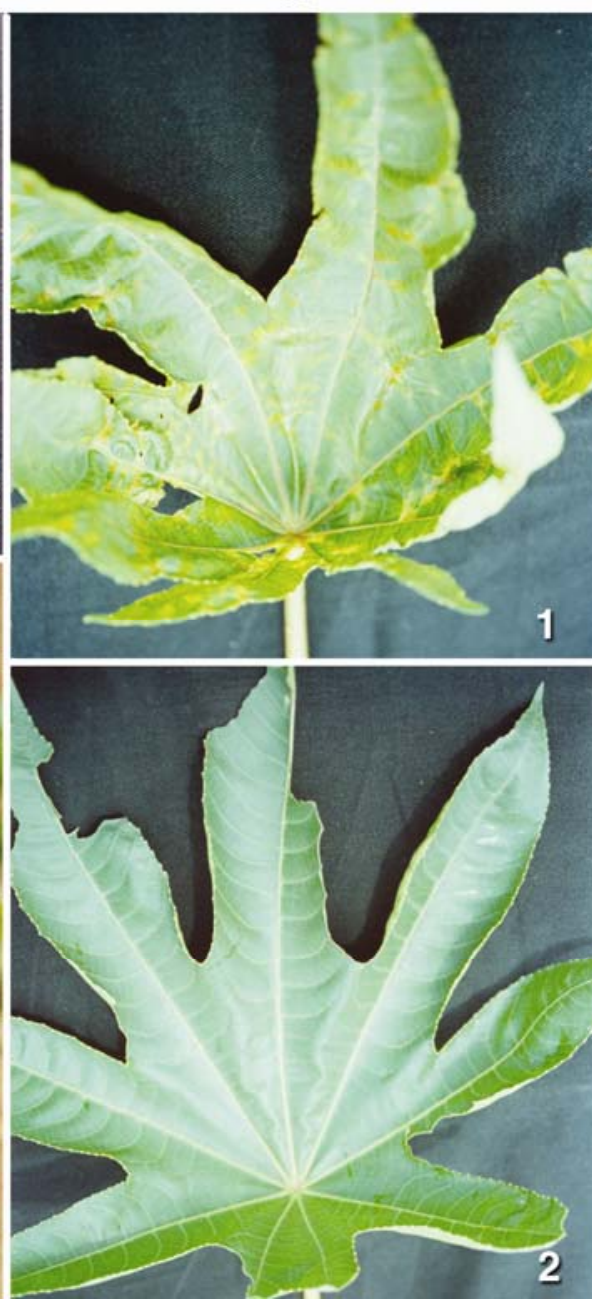

Fig. 5. Natural hosts of African cassava mosaic virus (ACMV) and East African cassava mosaic virus (EACMV) in Nigeria as identified in polymerase chain reaction. A, (i) = Infected Senna occidentalis (L.) Link; (ii) = healthy S. occidentalis; B, (i) = a healthy leaf (H) and two infected leaves (I) of Combretum confertum Lams.; (ii) = healthy plant of C. confertum Lams.; C, (i) = infected leaf of Ricinus communis $\mathrm{L}$; and (ii) = healthy leaf of $R$. communis. 


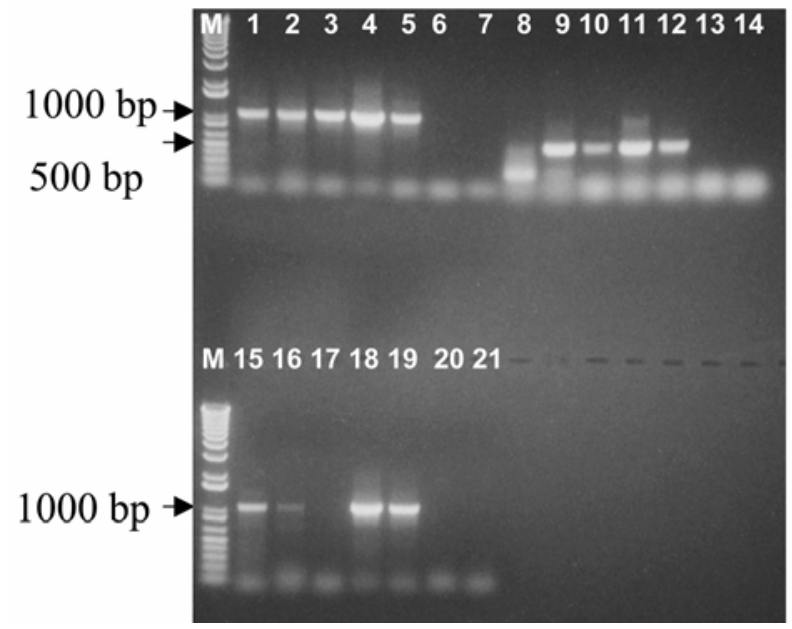

Fig. 6. Gel electrophoresis of DNA fragments of African cassava mosaic virus (ACMV) and East African cassava mosaic virus (EACMV) in weed samples in cassava fields in Nigeria amplified in polymerase chain reaction by three pairs of primers. Lanes 1-4 contained total DNA of weed samples Senna occidentalis (L) Link), Combretum confertum Lams., castor oil plant Ricinus communis L., and wild cassava (Manihot glaziovii Muller von Argau), respectively; lane 5 = DNA of cassava leaf coinfected by ACMV and EACMV as positive control; lane $6=$ DNA of healthy cassava leaf as negative control; and lane $7=$ buffer, also as negative control. This arrangement was repeated in lanes 8-11, 12, 13,14 , and $15-18,19,20,21$. The samples were tested by the following primers: lanes $1-7=$ ACMVAL1/F/AR0/R designed for open reading frames (ORFs) AC1/AV2 of ACMV (22); lanes 8-14 = primers $\mathrm{A} / \mathrm{B}$ for the common region of whitefly-transmitted geminiviruses (4); lanes $15-21=\mathrm{UV}$ $\mathrm{AL} 3 / \mathrm{F} / \mathrm{AL} 1 / \mathrm{R} 2$ for ORFs AC3/AC1 of most strains of EACMV (22).

and $\mathrm{B}$ ) has added them to the list of natural hosts of the viruses. Earlier, Shoyinka et al. (19) had reported castor oil plant $(R$. communis) as a natural host of ACMV and EACMV. In the present survey, ACMV also was detected in $R$. communis leaves (Fig. 6). R. communis and the newly identified natural hosts of ACMV and EACMV (Fig. 5A and B) are fairly common in southern Nigeria. The wider host range of ACMV is of epidemiological importance because the natural hosts could serve as reservoirs of inoculum.

EACMV-Ug2 was not detected in Nigeria (Fig. 3). This implies that the virulent Ugandan variant has neither manifested itself nor been introduced. This corroborates the earlier report by Ogbe (11). Negative results obtained for the diagnosis of ICMV and SACMV also indicate that these viruses might not be present in Nigeria. The unidentified isolates (Fig. 2) need to be further characterized; they could be strains of cassava mosaic begomoviruses. Genetic modification by mutation or recombination of geminiviruses has produced new species and strains such as EACMV-Ug2 (22) and SACMV (2).

Although the virulent Ugandan variant apparently was not present in Nigeria, the high proportion of double infections by ACMV and EACMV and the occurrence of variants of ACMV (Fig. 4) provide suitable conditions for the possible evolution of new strains or species of cassava begomoviruses. Therefore, Appropriate measures are necessary to safeguard cassava production. The timely CMD project is providing additional resistant cassava genotypes for farmers to forestall the con- sequence of any outbreak of a virulent strain or species of cassava begomovirus and also to minimize the impact of EACMV-Ug2 if it eventually spreads to Nigeria.

\section{ACKNOWLEDGMENTS}

The CMD project was co-sponsored by the Federal Government of Nigeria, the State Governments of the south-south and southeast geopolitical zones, Ondo State government, the Niger Delta Development Commission (NDDC), Nigerian National Petroleum Corporation (NNPC), Shell Petroleum Company, and the United States Agency for International Development (USAID)

\section{LITERATURE CITED}

1. Berrie, L. C., Palmer, K., Rybicki, E. P., and Rey, M. E. C. 1998. Molecular characterization of a distinct South African cassava infecting geminivirus. Arch. Virol. 143:2253-2260.

2. Berrie, L. C., Rybicki, E. P., and Rey M. E. C. 2001. Complete nucleotide sequence and host range of South African cassava mosaic virus: further evidence for recombination among begomoviruses. J. Gen. Virol. 82:53-58.

3. Bock, K. R., and Woods, R. D. 1983. Etiology of African cassava mosaic disease. Plant Sci. 67:994-995.

4. Dellaporta, S. L., Woods, J., and Hicks, J. B. 1983. A plant DNA mini-preparation: version II. Plant Mol. Biol. Rep. 1:19-21.

5. Deng, D., Mc Grath, P. F., Robinson, D. J., and Harrison, B. D. 1994. Detection and differentiation of whitefly-transmitted geminiviruses in plants and vector insects by the polymerase chain reaction with degenerate primers. Ann. Appl. Biol. 125:327-336.

6. Fargette, D., Fauquet, C., and Thouvenel, J. C. 1988. Yield losses induced by African cassava mosaic virus in relation to the mode and the date of infection. Trop. Pest Manage. 34:89-91.

7. Fondong, V. N., Pita, J. S., Rey, M. E. C., de Kochko, A., Beachy, R. N., and Fauquet, C. M. 2000. Evidence of synergism between African cassava mosaic virus and a new doubleCameroon. J. Gen. Virol. 81:287-297. recombinant geminivirus infecting cassava in
8. Harrison, B. D., Zhou, X., Otim-Nape, G. W. Liu, Y., and Robinson, D. J. 1997. Role of a novel type of double infections in the geminivirus-induced epidemic of severe cassava mosaic in Uganda. Ann. Appl. Biol. 131:437-448.

9. Hong, Y. G., Robinson, D. J., and Harrison, B. D. 1993. Nucleotide sequence evidence for the occurrence of three distinct whiteflytransmitted geminiviruses in cassava. J. Gen. Virol. 74:2437-2443.

10. Neuenschwander, P., Hughes, J. d'A., Ogbe, F. O., Ngatse, J. M., and Legg, J. P. 2002. Occurrence of the Uganda variant of East African cassava mosaic virus (EACMV-Ug) in western Democratic Republic of Congo and the Congo Republic defines the westernmost extent of the CMD pandemic in East/Central Africa. Plant Pathol. 51:385.

11. Ogbe, F. O. 2001. Survey of cassava begomoviruses in Nigeria and the response of resistant cassava genotypes to African cassava mosaic begomovirus infection. Ph.D. thesis, University of Ibadan, Ibadan, Nigeria.

12. Ogbe, F. O., Atiri, G. I., Dixon, A. G. O., and Thottappilly, G. 2003. Serological and biological variations of African cassava mosaic virus in Nigeria. Ann. Appl. Biol. 143:203-213.

13. Ogbe, F. O., Legg, J., Raya, M. D., Muimbakankolongo, A., Theu, M. P., Kaitisha, G. Phiri, N. A., and Chalwe, A. 1997. Diagnostic survey of cassava mosaic viruses in Tanzania, Malawi, and Zambia. Roots 4:12-15.

14. Ogbe, F. O., Thottappilly, G., and Quin, F. M. 1997. Implementation in Africa of serological diagnostic test for cassava mosaic geminiviruses. Afr. J. Root Tub. Crops 2:33-36.

15. Otim-Nape, G. W., Bua, A., Thresh, J. M., Baguma, Y., Ogwal, S., Ssemakula, G. N., Acola, G, Byabakama, B., Colvin, J., Cooter, R. J., and Martin, A. 2000. The Current Pandemic of Cassava Mosaic Virus Disease in East Africa and Its Control. Natl. Agric. Res. Organ. (NARO), Uganda; Nat. Res. Inst. (NRI), University of Greenwich, UK; and Dept. Int. Dev. (DFID), UK; Hobbs the Printers Ltd. Totton, Hampshire, UK.

16. Otim-Nape, G. W., Shaw, M. W., and Thresh, J. M. 1994. The effects of African cassava mosaic geminivirus on the growth and yield of cassava in Uganda. Trop. Sci. 34:43-54.

17. Pita, J. S., Fondong, V. N., Sangare, A., Kokora, R. N. N., and Fauquet, C. M. 2001. Genomic and biological diversity of the African cassava geminiviruses. Euphytica 120:115-125.

18. Pita, J. S., Fondong, V. N., Sangare, A., OtimNape, G. W., Ogwal, S., and Fauquet, C. M 2001. Recombination, pseudo-recombination and synergism of geminiviruses are determinant keys to the epidemic of severe cassava mosaic disease in Uganda. J. Gen. Virol. 82:655-665.

19. Shoyinka, S. A., Thottappilly, G., McGrath, F. F., and Harrison, B. D. 2001. Detection, relationships and properties of cassava mosaic geminivirus in naturally infected castor oil plant, Ricinus communis L. in Nigeria. Page 20 in: The Book of Abstracts, Fifth Conf. Cassava Biotech. Network (CBN-V), Donald Danforth Plant Science Center, St. Louis.

20. Swanson, M. M., and Harrison, B. D. 1994 Properties, relationships and distribution of cassava mosaic geminiviruses. Trop. Sci. 34:15-25.

21. Terry, E. R. 1975. Description and evaluation of cassava mosaic disease in Africa. Pages 5354 in: The International Exchange and Testing of Cassava Germplasm in Africa. E. R. Terry and R. Maclntyre, eds. IITA, Ibadan, Nigeria.

22. Zhou, X., Liu, Y., Calvert, L., Munoz, C., OtimNape, G. W., Robinson, D. J., and Harrison, B. D. 1997. Evidence that DNA-A of a geminivirus associated with severe cassava mosaic disease in Uganda has arisen by interspecific recombination. J. Gen. Virol. 78:2101-2111. 